\title{
Productivity and water use of an irrigated high country pasture
}

\author{
R.J. PATON and P.B. GREENWOOD \\ AgResearch, Invermay Agricultural Centre, Private Bag 50034, Mosgiel
}

\begin{abstract}
Pasture production and irrigation water-use efficiencies were measured for 3 irrigation regimes on a Mackenzie shallow, stony soil in the Mackenzie Basin near Omarama. Irrigating at 25\% was the most efficient of three irrigation frequencies maintained over the 198 1-1986 period (irrigated at $0 \%, 25 \%$, and $50 \%$ plant-available water capacity). Less frequent irrigation resulted in lower pasture yields due to increased water stress, while more frequent watering resulted in a $55 \%$ drainage loss of irrigation water below the root zone. At $1.16 \mathrm{t}$ DM/ha per irrigation, the increase in pasture yield with irrigation at $25 \%$ was higher than most increases achieved in existing irrigation schemes in Central Otago and mid Canterbury. Over 6 years, this treatment required 4-7 irrigations annually and, on average, produced $6.0 \mathrm{t} \mathrm{DM} / \mathrm{ha}$ more than did dryland pasture. The water-use efficiencies achieved in the border-strip irrigation system used were generally greater than expected for highly permeable stony soils where large drainage losses of irrigation water below the root zone are common. This was the result of reduced soil water

\section{- transmission rates after compaction by heavy} machinery during border strip* preparation. That effect of compaction was persistent, and had not diminished 9 years after initial pasture and irrigation development, as structural improvement of this soil is slow, even under irrigation.
\end{abstract}

Keywords: high country pasture, irrigation, Mackenzie Basin

\section{Introduction}

In the Mackenzie Basin, a high country area in North Otago characterised by hot, dry summers, dryland pastures developed with traditional grass and clover mixtures exhibit low productivity and poor persistence. Cossens (1990), for instance, reported an average annual pasture yield of only $1.7 \mathrm{t} / \mathrm{ha}$ near Omarama. More drought-tolerant species of grasses and legumes have been introduced to improve pasture performance in such environments but, while several show considerable promise, many are slow to establish and of low persistence (Woodman et al. 1992).

In some areas of the high country where water is available, irrigation may be a viable alternative to increase productivity. At Tara Hills High Country Research Station close to Omarama, irrigation has been employed since 1950, and irrigated pastures comprising traditional species there can produce $10.0 \mathrm{t} \mathrm{DM} / \mathrm{ha} / \mathrm{yr}$ (Greenwood 1982). In the Mackenzie Basin, irrigation water can be drawn from canals associated with a hydroelectricity scheme and, in the past, irrigation schemes have been considered for this area (O'Connor 1966). An earlier soil survey classified local soils in terms of their suitability for irrigation (Webb 1981).

This paper reports the results of an irrigation study conducted in the Mackenzie Basin between 1980 and 1986. The production and persistence of dryland and irrigated pastures were examined together with irrigation requirements and efficiency of water use. Early results have been reported by Greenwood \& Paton (1985).

\section{$M$ ethods}

This experiment was conducted on Glenbrook Station $18 \mathrm{~km}$ north of Omarama, at $480 \mathrm{~m}$ asl. Annual rainfall at ${ }^{-} \mathrm{T}$ wizel,, $10 \mathrm{~km}$ north of the site, averaged $323 \overline{\mathrm{mm}}$ during the 6 year duration of the experiment. The soil is a Mackenzie shallow sandy loam with areas of a more stony phase associated with relic stream channels. Overall, the mean stone-free soil depth is $22 \mathrm{~cm}$ underlain by $40 \mathrm{~cm}$ of very stony, loamy sand. Plantavailable water capacity is approximately $75 \mathrm{~mm}$. This Mackenzie soil is representative of approximately 20 000 ha of potentially irrigable land in the Mackenzie Basin.

After 3 years of pasture establishment studies following development from native fescue tussock, 3 irrigation treatments were imposed on the 5.5 ha experiment. Water was applied by an automated border strip method at 0\%, 25\% and 50\% AWC (available soil water capacity) to grazed plots of approximately 0.3 ha. The three irrigated, and one dryland, treatments were laid out in a randomised block design with 3 replicates.

Each plot, comprising a single border strip, was irrigated separately at a flow rate of $60 \mathrm{l} / \mathrm{s}$. Quantities of irrigation water applied to the irrigated plots were 
recorded for later calculations of water use efficiencies. Pasture composition and growth rates were measured. Maintenance fertiliser was $375 \mathrm{~kg} / \mathrm{ha}$ superphosphate for the first 2 years of the experiment. For the remaining 4 years, the experiment received $250 \mathrm{~kg} / \mathrm{ha}$ sulphur superphosphate annually. Further details of design and measurements have been reported by Greenwood \& Paton (1985).

\section{Results and discussion}

\section{Dryland pasture production}

In this severe Mackenzie climate, annual dryland pasture yield averaged only $1.75 \mathrm{t}$ DM/ha between 1980 and 1986 (Table 1), approximately 40\% lower than that reported by Radcliffe \& Cossens (1974) for dryland Central Otago pasture. The difference most likely reflects a $25 \%$ lower plant-available water capacity in the Glenbrook soil resulting in a greater incidence of drought conditions. The severity of such conditions is clearly reflected in poor persistence of both ryegrass and clover as, after intial establishment of the pasture in 1977, successive summer droughts resulted in such a rapid decline of both species that, by spring 1983, overdrilling was necessary. However, soon after resowing, ryegrass and clover again suffered severely from drought conditions and by the end of the experiment in 1986, both comprised only about $15 \%$ of the sward (Table 2). The remainder consisted of annual grasses (Bromus mollis L., Bromus tectorum L., and Vulpia bromoides

Table 1 Annual dry matter yields.

\begin{tabular}{|c|c|c|c|c|c|c|c|}
\hline Treatment & $1980 / 81$ & $81 / 82$ & $\begin{array}{c}\text { Dry } n \\
82 / 83\end{array}$ & $\begin{array}{l}\text { atter yiel } \\
\text { ear } \\
83 / 84\end{array}$ & (t/ha) & $85 / 86$ & $\begin{array}{c}\text { Mean } \\
1980-86\end{array}$ \\
\hline Dry & 1.20 & 1.52 & 1.30 & 1.04 & 2.70 & 1.39 & 1.65 \\
\hline $0 \%$ AWC & 5.97 & 5.13 & 4.52 & 6.16 & 7.79 & 6.36 & 5.99 \\
\hline $25 \%$ AWC & 7.75 & 6.94 & 6.00 & 0.92 & 0.23 & 0.32 & 7.71 \\
\hline $50 \%$ AWC & 7.36 & 7.75 & 7.95 & 0.69 & 0.97 & 0.59 & 0.39 \\
\hline LSD $(P<0.05)$ & 1.59 & 1.40 & 1.90 & 1.26 & 0.76 & 0.71 & 0.50 \\
\hline
\end{tabular}

Table 2 Proportions of ryegrass and clover in dryland and irrigated (25\% AWC) treatments.

\begin{tabular}{llccccc}
\hline & Year & & & & & \\
& Treatment & $80 / 81$ & $81 / 82$ & $82 / 83$ & $83 / 84$ & $85 / 86$ \\
\hline Ryegrass \% & Dryland & 10 & 0 & 4 & 1 & 13 \\
& 25\% AWC & 10 & 26 & 14 & 10 & 37 \\
& LSD (P<0.05) & 5 & 16 & .11 & 4 & 15 \\
White & Dryland & 45 & 1 & 2 & 15 & 10 \\
clover \% & 25\% AWC & 45 & 50 & 57 & 60 & 30 \\
& LSD (P<0.05) & 11 & 0 & 11 & 0 & 10 \\
\hline
\end{tabular}

L.), sweet vernal (Anthoxanthum odoratum L.) and sorrel (Rumex acetosella L.).

\section{Irrigated pasture production}

Irrigation at $25 \% \mathrm{AWC}$, i.e. when $75 \%$ of plant-available water had been depleted, resulted in an average annual pasture yield which was 3.6 times $(6.0 \mathrm{t} \mathrm{DM} / \mathrm{ha})$ higher than that of dryland (Table 1). This result closely matches irrigation improvements reported from a Central Otago experiment in a similar environment but on a deeper soil (Radcliffe \& Cossens 1974), and exceeds that achieved by Scott \& Maunsell (198 1) of a 2.7-fold improvement for ungrazed white clover in pure swards in the Mackenzie Basin. In the present work, annual yield increases ranged from approximately $7.0 \mathrm{t} \mathrm{DM} / \mathrm{ha}$ during two of the six years, to a low of $4.7 \mathrm{tDM} / \mathrm{ha}$ during 1982/83 when grass grub damage to the irrigated swards was evident. The irrigated plots were consequently overdrilled then, at the same time as were the dryland plots. After sward rejuvenation, annual irrigated yields increased by about $2.0 \mathrm{t} \mathrm{DM} / \mathrm{ha}$.

Following initiation of growth in mid September, the dryland growth rate increased to $13.8 \mathrm{~kg} \mathrm{DM} / \mathrm{ha}$ day at the end of October (Figure 1). Production then declined through the dry summer period so that, in total, $50 \%$ of annual growth occurred in the spring and $40 \%$ in summer (Figure 2). In contrast, the irrigated pasture grew much more rapidly during spring when ryegrass dominated the sward. Although production then declined slightly, white clover growth increased rapidly in late November to become the dominant species. The peak growth rate of $50.8 \mathrm{~kg} \mathrm{DM} / \mathrm{ha} /$ day was attained in mid December. Irrigation then maintained high growth rates relative to the dryland pasture until the onset of cooler autumn conditions in March. Growth in both swards ceased by early May. Similar patterns of growth were reported by Radcliffe \& Cossens (1974) for Central Otago pastures (Figure 1).

On average, the least frequently irrigated treatment, i.e. that irrigated at $0 \%$ AWC, required 4.0 irrigations annually. Irrigating more frequently at $25 \%$ AWC required an additional 1.5 irrigations (5.5 irrigations annually), whilst the most frequent watering regime $(50 \%$ AWC) demanded 8.0 irrigations per year (Table 3).

Over the six years of the experiment, the 1981-82 growing season was the driest (Figure 3), with dryland soil water contents below $25 \%$ AWC for more 
Figure 1 Rate of pasture growth for dryland and irrigated pastures, and comparisons with irrigated pastures in the Lower Waitaki Valley near Oamaru (Greenwood \& Sheath 198 1) and in Central Otago near Alexandra (Radcliffe \& Cossens 1974).

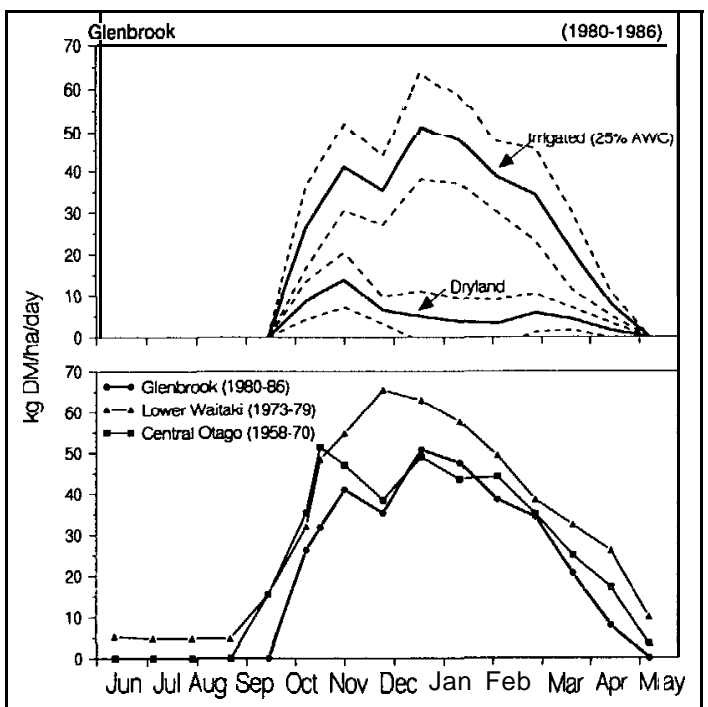

Table 3 Irrigation details and efficiencies (means for 19811986).

\begin{tabular}{lcccc}
\hline Treatment & $\begin{array}{c}\text { Number of } \\
\text { irrigations } \\
\text { per year } \\
\text { t DM/ha }\end{array}$ & $\begin{array}{c}\text { Water } \\
\text { applied per } \\
\text { irrigation } \\
(\mathrm{mm})\end{array}$ & $\begin{array}{c}\text { Additional } \\
\text { DM yield } \\
\text { per } \\
\text { irrigation }\end{array}$ & $\begin{array}{c}\text { Irrigation } \\
\text { efficiency* } \\
(\%)\end{array}$ \\
\hline 0\%-AWC & $4: 0$ & 69 & 1.06 & $105-1.06$ \\
$25 \%$ AWC & 5.5 & 70 & 1.16 & 72 \\
$50 \%$ AWC & 8.0 & 78 & 0.81 & 45 \\
\hline
\end{tabular}

- Irrigation efficiency $=$ Soil water deficit $\times 100$ Irrigation water applied

than half of the season. During that year, 6 irrigations were applied to the 25\% AWC treatment, while in the season with highest rainfall (1983-84), and associated high soil water contents, 2 less irrigations were required. Overall, 3-5, 4-7 and 4-10 irrigations were applied to the $0 \%, 25 \%$, and 50\% AWC treatments respectively during the six years. In general, these irrigation needs for this high country Mackenzie Basin site, were comparable with those reported for a shallow stony soil of similar water-holding capacity within the Valetta irrigation scheme in mid Canterbury (Hayman \& McBride, 1979).

Irrigating at $0 \%$ AWC, i.e. at 'wilting point' increased mean annual pasture yield over that of dryland by $240 \%$ (4.24 t DM/ha). More frequent irrigation at
Figure 2 Seasonal dry matter yields.

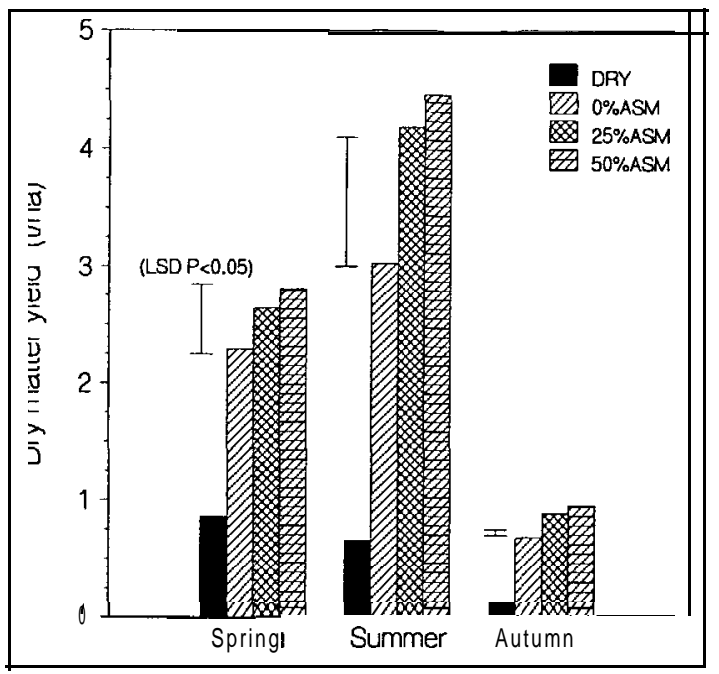

25\% AWC resulted in au additional annual yield of 1.8 t DM/ha (30\%), whilst the most frequent watering regime increased production by only a further $0.45 \mathrm{t}$ $\mathrm{DM} / \mathrm{ha}(5 \%)$. These relative responses between irrigation treatments are very similar to those reported by Hayman \& McBride (1979) for the same irrigation regimes on stony soils of similar physical characteristics in Canterbury. However, because dryland pasture production is significantly lower in the Mackenzie high country than in lowland Canterbury, the increase in yield per irrigation was highest there. With irrigation at $0 \%$ AWC $^{-}$, the Glenbrook experiment ${ }^{-}$retumed $^{-} 1^{-0}{ }^{-}{ }^{-}$ $\mathrm{DM} / \mathrm{ha}$ per irrigation compared with $0.38 \mathrm{t} \mathrm{DM} / \mathrm{ha}$ in Canterbury. At 25\% AWC the relative returns for the two sites were 1.16 and $0.42 \mathrm{tDM} / \mathrm{ha}$ for Glenbrook and Canterbury, respectively. Indeed, the dry matter responses per irrigation at 25\% AWC in the Mackenzie are higher than those reported for seven different soils within established irrigation schemes in mid Canterbury (Hayman \& McBride (1979). Those soils varied from a shallow stony soil similar to that at Glenbrook, to a deep, stone-free soil with a water-holding capacity in excess of $180 \mathrm{~mm}$

\section{Irrigationefficiencies}

Of the three irrigation treatments, irrigating at $25 \%$ AWC provided the greatest increase in DM yield per irrigation. Indeed, it is widely recognised that this "watering regime is the most appropriate for general practice, and is widely employed within irrigation schemes. Irrigating at a greater water deficit (e.g. at $0 \%$ AWC) results in increased plant water stress and lower DM yields, whereas irrigating more frequently 
results in inefficient use of water through drainage losses (Cossens 1982; Rickard et al. 1986). In the Glen-brook study, only the $0 \%$ AWC treatment fully restored plantavailable water without such losses of water by drainage. In irrigating at $25 \%$ AWC, when $20 \mathrm{~mm}$ less water was required to restore plant-available water to capacity, approximately $30 \%$ of the irrigation water applied was lost by drainage below the root zone (Table 3). Irrigating even more frequently at $50 \%$ AWC increased this loss to $55 \%$.

The irrigation efficiencies attained probably represent the highest that may be achieved on these soils by border-strip irrigation. Water contents were measured regularly, irrigations were scheduled strictly according to target water contents, and the border strip method used was automated with a pneumatic release system. Indeed, the $72 \%$ irrigation efficiency achieved when irrigating at $25 \%$ AWC was considerably

higher than many efficiencies

reported for border-strip irrigation of a range of Central Otago soils (Cossens 1982).

Irrigation efficiency is strongly influenced by design parameters such as border length and water application rate, and also by soil factors such as water deficit at irrigation, rooting depth, and particularly infiltration rate and root zone hydraulic conductivity. Shallow, stony soils often exhibit rapid water transmission resulting in large losses of water below the root zone under borderstrip systems (Cossens 1982). In its native state, the Mackenzie soil employed in the current study is highly permeable but, during border strip preparation, soil compaction associated with the passage of heavy machinery resulted in a significant increase in soil dry bulk density (from 1.00 to $1.44 \mathbf{g} / \mathrm{cm}^{3}$ ) and in a reduction in the rate of water transmission through the soil (from $2.2 \times 10^{-5}$ to $5.5 \times 10^{-6} \mathrm{~m} / \mathrm{s}$ ). This effect of compaction no doubt played a major part in achieving high water use efficiencies relative to those reported for other irrigation studies. It was expected that, during the 6 years of the experiment, the degree of soil compactness would gradually decrease as a result of improved root growth and organic activity. In practice, however, this did not occur as structural development of this soil is slow after initial improvement, even under irrigation. Consequently, the efficiency of irrigation of such high country soils is likely to remain high for a significant time after initial development.

\section{Conclusions}

1. Irrigation can increase production of improved ryegrass/clover pastures on shallow, stony Mackenzie Basin soils by approximately 3.5 times (6.0 t/ha). When watered at $25 \%$ AWC over a 6 . year period, irrigated pasture attained a peak growth rate of $51 \mathrm{~kg} \mathrm{DM} / \mathrm{ha} /$ day and, relative to dryland pasture, maintained a high rate of growth throughout the September to May growing season.

2. In the dry Mackenzie Basin environment, the numbers of irrigations required to maintain soil water contents above $0 \%, 25 \%$, and $50 \%$ plant-available water capacity were, on average, very similar to reported requirements for comparable soils within Central Otago and mid Canterbury irrigation schemes. Pasture responses per irrigation, however, were highest in the Mackenzie because dryland production there is low.

3. Of the three irrigation frequencies tested, irrigating at $25 \%$ AWC was the most efficient in terms of additional dry matter production achieved per irrigation. This regime required 4-7 irrigations 
annually. Less frequent irrigation resulted in lower pasture yields due to increased water stress, while more frequent watering resulted in a 55\% drainage loss of irrigation water below the root zone.

4. In irrigating at $25 \%$ AWC, irrigation efficiency was approximately $70 \%$, with a drainage loss of approximately $30 \%$ of the water applied. For such a permeable soil, this efficiency in a border-strip system is high, and considerably better than most reported for a range of Central Otago soils within existing irrigation schemes. It is probably due to the persistent effects of soil compaction during borderstrip formation with heavy machinery.

\section{ACKNOWLEDGEMENTS}

The Kelland family (Glenbrook Station) for use of their land and stock, and John Pedofsky and other Tara Hills staff for assistance.

\section{REFERENCES}

Cossens, G.G. 1982. The response of pasture to irrigation in Central Otago. Invermay Agricultural Research Centre Technical Report No. 11. New Zealand Ministry of Agriculture and Fisheries. $34 \mathrm{pp}$.

Cossens, G.G. 1990. Pasture and luceme production in Otago and Southland 1950 -1987. Invermay Agricultural Research Centre Technical Report No. 21. New Zealand Ministry of Agriculture and Fisheries. $31 \mathrm{pp}$.

Greenwood, P.B._1982._Irrigation.research.at_Tara.Hills High Country Research Station 1948 to 1982. Invermay Agricultural Research Centre Technical Report No. 13. New Zealand Ministry of Agriculture and Fisheries. $165 \mathrm{pp}$.
Greenwood, P.B.; Paton, R.J. 1985. Irrigation of a high country MacKenzie soil. Proceedings of the New Zealand Grassland Association 46: 25-30.

Greenwood, P.B.; Sheath, G.W. 1981. Seasonal distribution of pasture production in New Zealand XVI. The Lower Waitaki Plains, North Otago. New Zealand journal of experimental agriculture 9: 151155.

Hayman, J.M; McBride, S.D. 1979. The effect of soil and rainfall on the response of pasture to irrigation. Proceedings of the Agronomy Society of New Zealand 9: 121-124.

O'Connor, K.F. 1966. A scientific basis for potential use of land in the Mackenzie. Proceedings of the Lincoln College Farmers Conference 16:77-87.

Radcliffe, J.E.; Cossens, G.G. 1974. Seasonal distribution of pasture production in New Zealand. III. Central Otago. New Zealand journal of experimental agriculture 2: 349-358.

Rickard, D.S.; McBride, S.D.; Fitzgerald, P.D. 1986. The effect of soil moisture deficits on pasture yield. New Zealand agricultural science 20: 7-12.

Scott, D.; Maunsell, A.L. 1981. Pasture irrigation in the MacKenzie Basin. 1. Species comparison. New Zealandjournal of experimental agriculture 9:279290.

Webb, T.H. 1981. Suitability of land for irrigation between Tekapo and Ohau Rivers, MacKenzie Basin. Department of Scientific and Industrial Research, New Zealand. Soil Bureau District Office Report Ch 7.

_Woodman,_R.F.;_Keoghan,_J.M.;_Allan,_B.E._1992 Pasture species for drought prone lower slopes in the South Island high country. Proceedings of the New Zealand Grassland Association 54: 115-1 20. 